\title{
The Formation of Strategic Priorities for Development of Industrial Enterprises of the Samara Region
}

\author{
Marina V. Simonova ${ }^{1}$ \\ Aleksey V. Streltsov² \\ Vladimir A. Noskov ${ }^{3}$ \\ ${ }^{1}$ Samara State University of Economics, Russia, 443090, Samara, 141, Sovetskoi Armii Street \\ 2Samara State University of Economics, Russia, 443090, Samara, 141, Sovetskoi Armii Street \\ ${ }^{3}$ Samara State University of Economics, Russia, 443090, Samara, 141, Sovetskoi Armii Street \\ Correspondence: Marina V. Simonova, Samara State University of Economics, Russia, 443090 \\ Samara, 141, Sovetskoi Armii Street, e-mail: m.simonova@mail.ru
}

Doi:10.5901/mjss.2015.v6n6s3p309

\section{Abstract}

The aim of this work is to develop strategic priorities for development of industrial enterprises in the Samara region of Russia. The paper analyzes the dynamics of economic and financial indicators, identifies the factors that determine their development, taking into account specifics of the industry and importance of the regions, the article identifies the groups of production, distinguished by their characteristics. The authors identify the problems hindering sustainable development of enterprises in the industrial complex of the Samara region, form and justify strategic priorities for development of industrial enterprises in the region, grouped by their economic activity.

Keywords: industrial enterprises, economic activities, manufacturing, industry, economic indicators, strategic priorities.

\section{Introduction}

In any developed country in the world the industrial complex is the leading element of the economy, which ensures development of all its branches, the dynamics of the gross natural product, determines the position of the country in the international division of labor (Drucker, J. (2011), (Neffke, F., Henning, M., \& Boschma, R. (2011). The industry in emerging economies can have both positive and negative factors of sustainable development (Luken, R., \& Castellanos Silveria, F. (2011). The industry of the Russian Federation is a priority area of the economy, but its state, dynamics and development do not fully meet modern requirements, and the economy has accumulated serious problems requiring development of a set of measures for their solution.

Formation of measures to improve development efficiency of the Russian industry requires certain strategic priorities of industrial enterprises in various industries. Developing them we must take into account the trends of modern Russian economic situation, international approaches to the study of causes which influence the industry growth (BEKAERT, G., HARVEY, C., LUNDBLAD, C., \& SIEGEL, S. (2007), and the possibility of mutually beneficial international economic cooperation. It is necessary to assess the impact of regional industrial production features, urbanization and localization industry, which largely affect the growth of the manufacturing sector (Day, J., \& Ellis, P. (2013). All of this requires an analysis of industrial activities, identification of factors determining their development, grouping by some signs, identifying the problems hindering sustainable development.

\section{Research Methodology}

\subsection{The structure and target of research}

The structure of this research was determined by the following logical steps: the choice of the target - industrial enterprises of the Samara region, the analysis and assessment of their economic and financial indicators, identification of the factors that determine their development, grouping of companies, problem definition, creation and support of strategic development priorities. The methods are justified by the relevance of structural changes in the economy of the region and 
growth in industrial sectors (Castellacci, F. (2010)1. The choice of the target of this research at industrial enterprises of the Samara region is determined by the industry's leading place in the regional economy, high significance of individual companies in some industries (automotive, oil refining, chemical industry, etc.), in the industrial complex of Russia as a whole, common problems in development of industrial enterprises in modern conditions (A policy framework to strengthen EU manufacturing - towards a more integrated approach for industrial policy. (2005).

\subsection{Methods for achievement and assessment of industrial and outcome research results}

The analysis and assessment of economic and financial indicators were conducted in the dynamics calculating chain growth rate. Using input data of the Federal State Statistics Service of the Samara region, statistical information on industrial enterprises was studied separately under certain economic activities. The industry was justified as a combination of the following economic activities: "Mining and quarrying", "manufacturing", "Production and distribution of electricity, gas and water."

\section{Main Results}

\subsection{Analysis and assessment of economic and financial indicators.}

The industry of the Samara region is fairly well developed set of industries with predominance of manufacturing industries and among them - production of vehicles, and in particular the automotive industry. Very important role is played by extraction of fuel and energy resources, economic production, metallurgy, production of petroleum products, food beverages and tobacco, production, transmission and distribution of electricity, gas and water. The key economic indicators of the industry in the Samara region and their dynamics in the period 2008-2014 are presented in Table 1.

Table 1. The volume of shipped goods of own production, executed works and provided services on their own, the growth rate of output by economic activity of enterprises in the Samara region (Samara Statistical Yearbook. (2014).

\begin{tabular}{|c|c|c|c|c|c|c|}
\hline Indicators & 2008 & 2009 & 2010 & 2011 & 2012 & 2013 \\
\hline $\begin{array}{l}\text { Mining, manufacturing, production and distribution of electricity, } \\
\text { gas and water supply, mln. rub. }\end{array}$ & 716934,1 & 553135,3 & 744991,7 & 932896,3 & 1027351,6 & 1083050,6 \\
\hline The growth rate, $\%$ & 103,1 & 80,7 & 114,4 & 105,8 & 102,2 & 101,0 \\
\hline Mining, mln. rub. & 91841,3 & 90557,0 & 108289,6 & 145225,9 & 171701,9 & 186505,5 \\
\hline The growth rate, $\%$ & 104,6 & 107,7 & 105,0 & 103,1 & 104,0 & 103,0 \\
\hline Manufacturing, mln. rub. & 560941,7 & 393268,9 & 549311,0 & 689250,6 & 757031,0 & 780878,7 \\
\hline The growth rate, $\%$ & \begin{tabular}{|l|l}
104,0 \\
\end{tabular} & \begin{tabular}{|l|l|}
67,4 & \\
\end{tabular} & \begin{tabular}{|l|l|}
122,5 \\
\end{tabular} & 107,4 & 101,3 & 99,5 \\
\hline Production and distribution of electricity, gas and water, mln. rub. & 64151,1 & 69309,4 & 87391,1 & 98419,8 & 98618,7 & 115666,4 \\
\hline The growth rate, $\%$ & 95,8 & 89,7 & 97,3 & 104,0 & 100,0 & 106,4 \\
\hline
\end{tabular}

It may be noted that during the analyzed period, the volume of shipped goods (executed works and provided services) of industrial enterprises in the Samara region has grown by more than $50 \%$. However, mining and manufacturing and distribution of electricity, gas and water have provided most of this growth. The volume of shipped goods (executed works and provided services) for manufacturing grew at a modest pace. Having analyzed these types of economic activity only mining companies illustrated a stable pace of growth in shipped goods. The rate of growth in output of manufacturing, production and distribution of electricity, gas and water were not stable. Of course, you should take into account the impact of the crisis, which had an impact on the Russian economy in 2008. On the whole, the dynamics of these indicators can be regarded as positive, but the pace of growth is not stable and high enough, especially taking into account the actions of inflation.

The dynamics of financial results of companies in the same period is presented in Table 2.

Table 2. The net financial result (profit minus loss) of organizations by kinds of their economic activities, mln. rub. *

\begin{tabular}{|c|c|c|c|c|c|c|}
\hline Indicators & 2008 & 2009 & 2010 & 2011 & 2012 & 2013 \\
\hline Mining & 16321 & 29951 & 30117 & 44091 & 52442 & 77419 \\
\hline The growth rate & 45,9 & 183,5 & 100,6 & 146,3 & 118,9 & 147,6 \\
\hline Manufacturing & 24282 & -27776 & 36418 & 50839 & 58784 & 48554 \\
\hline The growth rate & 77,4 & - & - & 139,6 & 115,6 & 82,6 \\
\hline Production and distribution of electricity, gas and water & 2110 & 5355 & 7599 & 4725 & 2483 & 5873 \\
\hline The growth rate & 54,3 & 253,8 & 141,9 & 62,2 & 52,6 & 236,5 \\
\hline
\end{tabular}


We can notice from the presented data, the dynamics of the financial result generally corresponds, by studied economic activities, to the volume dynamics of shipped goods (executed works and provided services). At the same time, there are two important features which distinguish the trends in these indicators. Firstly, if the volume of shipped goods (executed works and provided services) and manufacturing exceeds mining, so considering the financial results, on the contrary, mining companies exceed manufacturing. And such relationships are formed during the study period due to different rates of growth indicators, especially against the background of manufacturing industry loss in 2009 . Secondly, we should note a greater fluctuation level of the financial result compared with the growth rate of shipped goods (executed works and provided services) for manufacturing, production and distribution of electricity, gas and water.

In general, the dynamics of financial results for the analyzed types of economic activity during the study period can be regarded as positive. However, growth rates are not stable and, taking into account manufacturing, do not correspond to their role in the industry of the Samara region (Boussabaine, A., \& Kirkham, R. (2005).

\subsection{Identifying the factors determining development of industrial enterprises in the Samara region.}

The most important factor in shaping the dynamics of indicators is the ratio required by market competitiveness of products and its level provided by industry (Leiponen, A. (2008). The degree of market monopolization is an important factor, including technological features of individual enterprises (Bransfield, S., \& Schlueter, D. (2004).

A more stable dynamics of growth in production of mining enterprises is determined by the fact that in spite of fluctuations in oil prices on world markets, the demand for products of these enterprises is relatively stable and, moreover, since there are vertically integrated companies, these companies are able to change the direction of a few finish production streams optimizing their production between exports and domestic manufacturing.

Among manufacturing industries there is a rather stable growth in production of companies which are combined by economic activity "Production of oil and oil products" as well as there are those ones which produce chemical products (in the structure of shipped goods, executed works and provided services $2013-7.2 \% ; 17.2 \%$, respectively ). With respect to these companies it can be noted that they, in fact, have a monopoly in their product range, as specific characteristics of their production (lack of access to raw materials, transport infrastructure, including power consumption and, most importantly, the capital intensity of production) create high barriers to entry the market. Product quality issues are also important to them; however, they are not as critical as, for example, for companies of other economic activities. Among the most important economic activities of the industry in the Samara region machine-building manufacturing enterprises differ by very unstable variations in rates of production. It is determined by availability of sufficient competitive market of machinery and equipment, as well as the fact that Russian machine-building enterprises, being significantly weakened during the years of market reforms, are forced to compete with more technically and economically viable foreign companies.

The main reason for this trend is permanent underinvestment of Russian machine-building enterprises of economic activities (Streltsov, A. (2014). During the period of 2005-2013 investment in mining enterprises, enterprises of chemical production, oil refining at times was higher than investment in machinery and equipment, manufacturing electrical, electronic and optical equipment. This ratio was better than the ratio of companies which manufacture vehicles. But even in this case, in 2013 investment in production of coke and oil products was 3 times higher than this indicator in production of vehicles. As a result of underinvestment in most enterprises the share of innovative, competitive products is not high enough; there is significant deterioration of capital, old technology. In order to overcome these tendencies it is necessary to implement some measures, primarily related to upgrading of products and production technologies.

\subsection{Grouping of industrial enterprises}

The most important factor in determining development of the industrial complex in the Samara region is that it depends a lot on the automotive industry and, in particular, the country's largest enterprise - "AvtoVAZ". In many respects, the decrease in the volume of shipped goods (executed works and provided services), output growth and the financial result in 2009 are determined by the state of affairs at the enterprise. We should note that the value of fixed assets for production of vehicles and equipment in 2008 amounted more than $66.4 \%$ of the value of this indicator for all manufacturing industries, the volume of shipped products - more than 40\%. By 2014, the share of car industry fell slightly, but it remained substantial.

An important role in terms of production volume and employment is also played by production of machinery and equipment and manufacture of electrical and optical equipment (Malmberg, A., \& Maskell, P. (2010). All these aspects allow you to define "machine-building" economic activities as the "core" of the industrial complex in the Samara region. 
Enterprises of this "core" have common specific characteristics. They have a continuous process of production, stages of production chain are quite diverse, but united in assembly production, which determines the existence of a large number of suppliers, subcontractors. At the same time components, produced by them, in many ways determine the quality of the final product in assembly production. Enterprises are science-intensive, new product development requires a significant amount of time and investment costs.

In terms of importance in the regional economy we can distinguish enterprises of so-called "second tier", which, having a more stable output growth, are starting to catch up, and in some cases surpassing machine-building enterprises. These are extractive industries, production of coke and petroleum products, chemical plants, steel production, production and distribution of electricity, gas and water. Most enterprises in these industries interact on a single technological chain (extraction of fuel and energy resources, production of coke and refined petroleum, chemical industry), and there is an organizational unity. It increases stability of these companies' activity in the market, and provides a more stable growth in production volumes.

Production of food products, including beverages and tobacco can be attributed to these significant economic activities. These enterprises have a quite stable share in the structure of shipped goods (executed works, provided services) and relatively high prospects of growth because they are mostly focused on the consumer, the final demand.

\subsection{Problem definition}

The problems that impede stable development at enterprises of the industrial complex in the Samara region vary greatly depending on the membership in a particular manufacturing group. The leading automotive company "AvtoVAZ" is in the process of restructuring, re-engineering and development of new models of products. Using the technical assistance of RENAULT - Nissan alliance the enterprise can significantly simplify the process. As a result, in 2013 the volume of innovative products and services for production of transport equipment amounted to $63 \%$ of the total volume of shipped goods, executed works and provided services, the volume of investments in the same year - $20 \%$ of the total value of manufacturing (Samara Statistical Yearbook, 2014).

At the same time, implemented modernization largely complicates the economy of the enterprise and does not encourage formation of a stable business environment. But it has much more impact on operational and financial results, the overall economic situation in the country, decrease of population solvency demand (Simonova, M., Bazhutkina, L., \& Berdnikov, V. (2015). Under these conditions, the enterprise is unable to increase the volume of sales rapidly, and it does not contribute to modernization of production.

For companies of other machine-building industries it can be noted that there are a number of problems, the existence of which is determined by constant underinvestment over the years of market reforms. These are a low level of products' competitiveness, insufficient research and development activities, reduction of technical and organizational level of production, difficulties in attracting highly qualified personnel (Weber, B., \& Alfen, H. (2010). A significant problem is the lack of organizational unity of adjacent manufacturing steps (Noskov, B. (2014).

Production, which makes a distinction between private independent enterprises, low technological level of procurement stages, lack of productivity and profitability, leads to a shortage of funds for necessary investments. Despite the fact that some enterprises are part of large companies ("Russian Machines", "United Engine Building Corporation", "European Bearing Corporation" and others.), the process of restructuring at these enterprises is not over, that does not allow many of them to be assisted by large integrated companies.

For businesses of oil refining, petrochemical and chemical industries the most important problem is a high wear of used equipment, technologies, and it leads to production of goods with insufficient quality or low added value. At the same time, these enterprises have a very important competitive advantage - most of them are part of large vertically integrated companies (JSCo "Rosneft", in some part - "Lukoil" and others.).

As a result, many of these enterprises have benefited from the support of integrated companies, and they carry out modernization of production. These enterprises have the largest amount of investment in the economy of the Samara region. For example, in 2013 it was more than $60 \%$ of their value in the whole manufacturing industry. However, investment projects, implemented by them, in connection with their specifics of production are very capital intensive with a long payback period, and it causes difficulty in their implementation and increases risk (Aho, E. (2012).

\subsection{Development and definition of strategic development priorities}

Differences in problems of enterprises, which belong to different economic activities, require formation of a different system of priorities in their development. 
For the automotive industry the most important priorities are modernization programs of production, expansion of the model range of machines, and cost optimization. Expected stabilization and improvement of the economic situation in Russia will significantly increase the demand. Among the positive factors that favorably influence easing of the situation in the automobile market it is necessary to mention the launch of the declared program of recycling second-hand cars, exit a number of competitors (Opel, General Motors), lower interest rates of banks, including car loans.

An important task for automotive companies and OJSC "AvtoVAZ" is to increase localization of components production in Russia, it will reduce costs and will help be more resistant to changes in exchange rates.

For enterprises manufacturing machinery and equipment, electrical and optical equipment the essential strategic priority is to complete the restructuring of production and formation of large integrated companies. To enter the effective level of economic activity it is necessary to implement large investment projects on a significant product innovation and technology to produce them. In this task it is advisable to use a different form of cooperation with more developed technically and technologically advanced companies, including foreign ones. The advantages of Russian companies in development of organizational forms of such cooperation are experience and established contacts in specific markets, availability of industrial sites with developed infrastructure, qualified staff. It should also be noted that, as it is shown by the data on the dynamics of economic activity, enterprises of this production quickly restore the positive trend of financial indicators, they have more stable profitability and by its average value over the past 5 years it is superior of profitability in production of vehicles in the metallurgical industry, in manufacture of food products, beverages and tobacco.

Enterprises of the mining complex, production of coke and petroleum products, chemical and metallurgical industries as a whole have completed restructuring, and formation of large integrated structures in them is completed. Therefore, strategic priorities of development at these enterprises are improving the product quality and processes through integrated companies. Possible areas of cooperation with other major companies and investors are to ensure joint development of production facilities, as well as acquisition of certain technology and equipment critical by certain specific enterprises of Russian integrated companies.

Enterprises that produce food products, beverages and tobacco, have a number of positive features that define the prospects for their development. They focus on consumer demand and due to the greater population of the Samara region, it (more than 3211 thousand people.) creates a steady market for them. Investment projects of these enterprises are characterized by a relatively small investment and short payback period. It should be noted that the restructuring of enterprises has not been completed yet. Therefore, strategic priorities of development at enterprises that produce food products, beverages and tobacco are to complete the restructuring process, increase presence in the markets of the Samara region and the nearby regions, based on product updates and applied technologies. It has great prospects for cooperation with major companies to produce food.

As the most promising organizational forms of mutual cooperation between enterprises one must admit their cooperation, in which all members maintain their independence and the rights of a legal entity. Among the most interesting are the co-joint ventures and common in the automotive industry so-called "strategic alliances". Among the most successful joint ventures in the Samara region can be noted CJSC "GM-AvtoVAZ", the cable company "PES / SCC" (with "General Motors"), JSC "Samara Optical Company" (together with "Corning Incorporated"). Realization of these forms, compared to direct entry of foreign companies into the Russian market, provides a more stable existence of enterprises, formation of the combined effect from existing strengths of all its members (Schiller, P. (2013). The current experience also shows that under difficult economic conditions and exit a number of foreign companies from the Russian market, the joint ventures of the industry continue to operate successfully in the Samara region.

\section{Discussion}

The subject for discussion on the results of this research may be the following.

First, identify the problems hindering sustainable development of industrial enterprises in the Samara region and their differentiation by groups of industries. Secondly, form development priorities for enterprises of certain types of economic activity.

Also under discussion could be proposed organizational form of cooperation between enterprises, including foreign companies (Drucker, J. (2011).

\section{Conclusion}

As a whole development of industrial enterprises in the Samara region has a positive trend, but the growth rate figures cannot be considered stable and they do not meet modern requirements. This is largely due to existing problems in the 
region's industry. It is possible to solve these problems on the basis of strategic priorities generated by economic activity. The further research may be directed to details of these priorities, taking into account the changing economic situation and a full understanding of specifics in some groups of companies.

\section{References}

A policy framework to strengthen EU manufacturing - towards a more integrated approach for industrial policy. (2005). Implementing the Community Lisbon Programme- European Commission, 474-474.

Aho, E. (2012). Innovation - a long lasting game. Vedomosti, p. Number 204 (3218). Retrieved April 26, 2015.

Bekaert, G., Harvey, C., Lundblad, C., \& Siegel, S. (2007). Global Growth Opportunities and Market Integration. The Journal of Finance Volume, Issue , Pages , June, 62(3), 1081-1137-1081-1137. doi:10.1111/j.1540-6261.2007.01231.x

Boussabaine, A., \& Kirkham, R. (2005). Whole life-cycle costing: Risk and risk responses. Oxford: Blackwell publishing group.

Bransfield, S., \& Schlueter, D. (2004). When joint ventures go bad. China Business Review, 31(5), 24-27.

Castellacci, F. (2010). Structural change and the growth of industrial sectors: empirical test of a GPT model. Review of Income and Wealth, 56(3), 449-482-449-482. doi:10.1111/j.1475-4991.2010.00380.x

Day, J., \& Ellis, P. (2013). Growth in Indonesia's manufacturing sectors: Urban and localization contributions. Regional Science Policy \& Practice Volume, 5(3), 343-368-343-368. doi:10.1111/rsp3.12015

Drucker, J. (2011). Regional Industrial Structure Concentration in the United States: Trends and Implications. Economic Geography, 87(4), 421-452-421-452. doi:10.1111/j.1944-8287.2011.01129.x

Hirschey, M., \& Dean, W. (1983). Indicators and causes of size advantages in industry. Managerial and Decision Economics, 4(2), 6472-64-72. doi:10.1002/mde.4090040203

Leiponen, A. (2008). Competing through cooperation: The organization of standard setting in wireless telecommunications. Management Science, 54(11), 1904-1919.

Luken, R., \& Castellanos -Silveria, F. (2011). Industrial transformation and sustainable development in developing countries. Sustainable Development, 19(3), 167-175-167-175. doi:10.1002/sd.434

Malmberg, A., \& Maskell, P. (2010). An evolutionary approach to localized learning and spatial clustering. In The Handbook of Evolutionary Economic Geography (pp. 391-405). Edward Elgar Publishing.

Neffke, F., Henning, M., \& Boschma, R. (2011). How Do Regions Diversify over Time? Industry Relatedness and the Development of New Growth Paths in Regions. Economic Geography, 87(3), 237-265-237-265. doi:10.1111/j.1944-8287.2011.01121.x

Noskov, B. (2014). Economic clusters of the Samara region and the basis of their scientific and educational framework. Vestnik of Samara State University of Economics, 7, 14-19.

Samara Statistical Yearbook. (2014). SAMARA, Samara: Samarastat.

Schiller, R. (2013). Irrational optimism as a market-driven, reckless behavior (Irrational Exuberance. Second Edition Revised \& Updated) (p. 422). Moscow: Alpina Publisher.

Simonova, M., Bazhutkina, L., \& Berdnikov, V. (2015). Approaches to the System Salary Increase in the Region on the Ground of Labor Production Growth. Review of European Studies, 7(2), 58-65. doi:10.5539/res.v7n2p58

Streltsov, A. (2014). Investments in development of the Samara region. Vestnik of Samara State University of Economics, 5, 37-44.

Weber, B., \& Alfen, H. (2010). Infrastructure as an asset class: Investment strategies, project finance and ppp (p. 284). John wiley \& sons. 